\title{
What next with environmental television broadcast?
}

\begin{abstract}
The existence of ecological journalism is important in public - service television. Its importance follows from interactions among the people. The conception of ecological journalism of fers continual information and its should be addressed to each spectator for example children, adults and business men. This ecological journalism is subject to program structure. This structure develops on a long-term basis. Television is a mass medium, which has influence on values of people. Very important are emotional experiences. The handover of environmental ideas are possible according the public - service television.
\end{abstract}

Keywords: environmental television broadcast, ecological journalism, ecology
Volume I Issue 6 - 2017

\author{
Erik Spano \\ Secondary vocational school of business and services, Slovakia
}

Correspondence: Erik Spano, Secondary vocational school of business and services, Sklenarova |352/I, 82 I 09 Bratislava, Slovakia,Tel 0944442066, Email erik.spano@seznam.cz

Received: September 28, 2017 | Published: December 28, 2017

\section{Introduction}

This institution has national and cultural basis. Independence is norm of this medium. When the television broadcast was advanced, the structure of television broadcast copied radio programme. The television broadcasts were transmitted cyclically. This television broadcast was called block magazine. The first environmental television broadcast was transmitted in 1950s. The spectators learned about development of life on the earth. This time was first examined feedback among the spectators. The new public phenomenon was used in educational field. In 1960s the environmental television courses started the show in television. In these environmental television courses was new way of communication without feedback. This television broadcast was different. Since 1989 television developments how many examples of ecological journalism. Living brings many questions for spectators. They can find the answers among environmental publicists. They are delegates of spectators. The ecological journalism brings the view in the social problems. Mutual analysis of ecological journalism can reach reconciliation between production and transmission. The ecological problems should represent the complex of ecological journalism in public service television. The ecological journalism should comprehend common spectator.

We can't forget on investigative ecological journalism. We should apply ecology of our soul. The ecology of our soul is mainly polite communication and empathy to the world. Ecological information has to be good processed and aesthetic. The public - service television should use the ideas, which are attractive for spectators. Researches of media analysts show that environmental television broadcast should be in a medium option. When we would like to be successful in this part of ecological journalism, we have to define the aim of ecological programmes.

\section{Acknowledgements}

None.

\section{Conflict of interest}

Author declares there is no conflict of interest in publishing the article. 